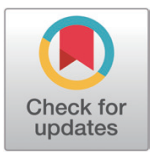

Received: Mar 11, 2021

Revised: Mar 31, 2021

Accepted: Apr 2, 2021

*Corresponding author

Hak-Jong Choi

Microbiology and Functionality

Research Group, Research and

Development Division, World Institute

of Kimchi, Gwangju 61755, Korea.

Tel: +82-62-610-1729

E-mail: hjchoi@wikim.re.kr

Jinho Park

Department of Veterinary Internal

Medicine, College of Veterinary

Medicine, Jeonbuk National University,

Iksan 54596, Korea.

Tel: +82-63-850-0949

E-mail: jpark@jbnu.ac.kr

Copyright $@ 2021$ Korean Society of Animal Sciences and Technology. This is an Open Access article distributed under the terms of the Creative Commons Attribution Non-Commercial License (http:// creativecommons.org/licenses/by$\mathrm{nc} / 4.0 /$ ) which permits unrestricted non-commercial use, distribution, and reproduction in any medium, provided

\section{The prevalence of causative agents of calf diarrhea in Korean native calves}

\author{
Jeong-Byoung Chae ${ }^{1}$, Hyeon-Cheol Kim², Jun-Gu Kang ${ }^{3}$, \\ Kyoung-Seong Choi ${ }^{4}$, Joon-Seok Chae ${ }^{1}$, Do-Hyeon $\mathrm{Yu}^{5}$, Bae-Keun Park ${ }^{6}$, \\ Yeon-su Oh ${ }^{2}$, Hak-Jong Choi ${ }^{7 *}$ and Jinho Park ${ }^{8 *}$
}

${ }^{1}$ Laboratory of Veterinary Internal Medicine, BK21 PLUS Program for Creative Veterinary Science Research, Research Institute for Veterinary Science and College of Veterinary Medicine, Seoul National University, Seoul 08826, Korea

${ }^{2}$ College of Veterinary Medicine and Institute of Veterinary Science, Kangwon National University, Chuncheon 24341, Korea

${ }^{3}$ Korea Zoonosis Research Institute, Jeonbuk National University, Iksan 54531, Korea

${ }^{4}$ College of Ecology and Environmental Science, Kyungpook National University, Sangju 37224, Korea

${ }^{5}$ Institute of Animal Medicine, College of Veterinary Medicine, Gyeongsang National University, Jinju 52828, Korea

${ }^{6}$ College of Veterinary Medicine, Chungnam National University, Daejeon 34134, Korea

${ }^{7}$ Microbiology and Functionality Research Group, Research and Development Division, World Institute of Kimchi, Gwangju 61755, Korea

${ }^{8}$ Department of Veterinary Internal Medicine, College of Veterinary Medicine, Jeonbuk National University, Iksan 54596, Korea

\section{Abstract}

Infectious calf diarrhea is one of the most significant diseases of neonatal calves. This study is conducted to identify the prevalence of pathogens in calf diarrhea for 2 years. A total of 544 feces samples from Korean native beef calves were obtained to investigate selected seven pathogens causing calf diarrhea: bovine rotavirus, bovine coronavirus, Cryptosporidium parvum, bovine viral diarrhea virus, Eimeria species, Escherichia coli K99, and Salmonella species. The presence of diarrhea, the number and species of detected pathogens, and the calves' ages were analyzed using various statistical methods depending on the case. Of the 544 calves, 340 calves (62.5\%) had normal feces and 204 calves $(37.5 \%)$ had diarrhea. The presence of pathogens was significantly associated with diarrhea $(p<0.01)$ and fecal scores and the number of detected pathogens showed a significant linear trend $(p<0.001)$. Of the 7 target pathogens, 6 were detected in samples, but only C. parvum $(p=0.001)$ and bovine rotavirus $(p<0.001)$ were found at significantly higher rates in diarrheic calves than in non-diarrheic calves. Only Eimeria spp. showed a significant linear trend between the detection rate of the pathogen and the age groups $(p<0.05)$.

Keywords: Calf diarrhea, Korean native beef calves, Enteric pathogens, Prevalence

\section{INTRODUCTION}

Infectious calf diarrhea is one of the most significant diseases of neonatal calves. It has affected 
the original work is properly cited.

ORCID

Jeong-Byoung Chae

https://orcid.org/0000-0003-3849-1063

Hyeon-Cheol Kim

https://orcid.org/0000-0002-8778-7277

Jun-Gu Kang

https://orcid.org/0000-0002-9083-8098

Kyoung-Seong Choi

https://orcid.org/0000-0002-2271-5360

Joon-Seok Chae

https://orcid.org/0000-0002-4813-3342

Do-Hyeon $\mathrm{Yu}$

https://orcid.org/0000-0001-7645-6926

Bae-Keun Park

https://orcid.org/0000-0003-1241-6452

Yeon-su Oh

https://orcid.org/0000-0001-5743-5396

Hak-Jong Choi

https://orcid.org/0000-0003-1185-0919

Jinho Park

https://orcid.org/0000-0001-5235-5717

Competing interests

The authors declare that they have no

competing interests.

Funding sources

This research was supported by Technology Development Program (Project No. 1116043-

1) for Bio-industry, Ministry for Agriculture, Food and Rural Affairs, Korea and partially supported by the National Research Foundation of Korea (NRF) grant funded by the Korea government (MSIT) (No. 2021R1A2C100517111) and by a research grant from the World Institute of Kimchi funded by the Ministry of Science and ICT, Korea (KE2101-1).

Acknowledgements

The authors would like to thank the owners of the cattle farms for cooperating with our research.

Availability of data and material Upon reasonable request, the datasets of this study can be available from the corresponding author.

Authors' contributions

Conceptualization: Choi KS, Chae JS, Yu

$\mathrm{DH}$, Park BK, Park J.

Data curation: Chae JB, Kim HC.

Formal analysis: Yu DH, Park BK, Oh Ys.

Methodology: Kim HC, Choi KS, Park J.

Software: Chae JB.

Validation: Choi HJ, Park J.

Investigation: Chae JB, Choi KS, Chae JS, Yu DH.

Writing - original draft: Chae JB, Kang JG, Choi KS, Yu DH.

Writing - review \& editing: Oh Ys, Choi HJ, Park J.

Ethics approval and consent to participate All procedures were performed according to ethical guidelines for the use of animal samples, as approved by Chonbuk National University (Institutional Animal Care and Use Committee [IACUC] Decision No. CBU 201600026). the morbidity and mortality of neonatal calves and their growth performances and has caused worldwide economic loss [1]. Even though various methods have been designed to treat calf diarrhea, prevention is still the best approach to reduce the disease, and monitoring for pathogens is one of the most important preventive actions [2]. Many researchers and reports worldwide have attempted to determine the prevalence of infectious pathogens in calf diarrhea [3-5]. Major pathogens causing calf diarrhea in these reports were: viruses (bovine coronavirus [BCV], bovine rotavirus group A [BRV], and bovine viral diarrhea virus [BVDV]), bacteria (Escherichia coli K99 and Salmonella spp.), and protozoa (Cryptosporidium parvum and Eimeria spp.). Some of the agents are known to be detected not only in diarrheic calves but also in normal calves.

In Korea, like other countries, calf diarrhea has had a serious impact on calf death. According to previous studies, $68.7 \%$ of calf deaths in Korean native beef calves and $53.4 \%$ in dairy calves were caused by digestive diseases [6,7]. Additionally, there have been several recent reports investigating pathogens that cause calf diarrhea [8-10]. However, most of them have been focused on specific pathogens from calf feces. As calf diarrhea can be caused by a variety of pathogens, it is necessary to simultaneously analyze different kinds of pathogens.

This study was performed to investigate the distribution of causative agents of calf diarrhea in Korean native beef calves aged less than 60 days in various regions of Korea and to discern their association with diarrhea.

\section{MATERIALS AND METHODS}

\section{Animals and sampling}

In this study, calves up to 60 days of age in 10 local Korean indigenous cattle farms in different areas of Korea (Yeongju, Samnye, Asan, Gimje, Mungyeong, Wanju, Heongseong, Sancheong, Iksan, Sangju) were selected for feces collection from 2016-2017. Feces were obtained by digital rectal palpation from the calves. All feces were scored as 0 to 3 using the scoring system included in the calf health scoring guide created by the University of Wisconsin-Madison School of Veterinary Medicine [11] and stored in $50 \mathrm{~mL}$ specimen bottles (SPL Life Sciences, Pocheon, Korea) at $4^{\circ} \mathrm{C}$ until they were transported to the laboratory. All feces scored at 2 and 3 were categorized as diarrhea.

\section{Pathogen detection}

All samples were examined for 7 pathogens (BCV, BRV, BVDV, C. parvum, Eimeria spp., E. coli K99, Salmonella spp.). Each feces sample was divided into two tubes and treated differently depending on the target agent, according to previously reported methods [8,12]. Briefly, to detect the 6 pathogens causing calf diarrhea (BCV, BRV, BVDV, C. parvum, E. coli K99, Salmonella spp.), fecal samples were suspended in $0.01 \mathrm{M}$ phosphate-buffered saline to make $30 \%$ fecal homogenates and centrifuged for $1 \mathrm{~min}$ at $100 \times \mathrm{g}$. A supernatant was used to extract the total nucleic acid using MagMAX $^{\mathrm{TM}}$ Total Nucleic Acid Isolation Kit (Thermo Fisher Scientific, Waltham, MA, USA). All extracts were stored at $-70^{\circ} \mathrm{C}$ until real-time polymerase chain reaction (PCR) was performed. Real-time PCR was performed with the Path-ID ${ }^{\mathrm{TM}}$ Multiplex One-Step RT-PCR kit (Life Technologies, Carlsbad, CA, USA) according to the manufacturer's recommended protocols in a $25 \mathrm{uL}$ reaction volume using $8 \mathrm{ul}$ of extracted template and $17 \mathrm{uL}$ of the reaction mixture. Two types of real-time PCR were performed using specific primer sets for each pathogen in Table 1: one for the 3 viruses (BCV, BRV, BVDV) and the other for the bacteria and protozoa (C.parvum, E. coli K99, Salmonella spp.). Equal volumes of primers and probes were mixed for each target agent and the final concentration of each primer and probe was $0.2 \mathrm{uM}$. Real-time PCR was 
Table 1. Nucleotide sequences of real-time polymerase chain reaction (PCR) primers and conditions for pathogens causing calf diarrhea

\begin{tabular}{|c|c|c|c|c|c|c|c|}
\hline \multirow[b]{2}{*}{ Type } & \multirow[b]{2}{*}{ Microbial agents } & \multirow[b]{2}{*}{$\begin{array}{l}\text { PCR primers, } \\
\text { probes and } \\
\text { conditions }\end{array}$} & \multicolumn{4}{|c|}{ Primer sequences $\left(5^{\prime}-3^{\prime}\right)$} & \multirow[b]{2}{*}{ Reference } \\
\hline & & & $\begin{array}{c}\text { Reverse } \\
\text { transcription } \\
\left({ }^{\circ} \mathrm{C} / \mathrm{min}\right)\end{array}$ & $\begin{array}{c}\text { Activation of } \\
\text { DNA } \\
\text { polymerase } \\
\text { ('C/min) }\end{array}$ & $\begin{array}{c}\text { Denaturation } \\
\left({ }^{\circ} \mathrm{C} / \mathrm{min}\right)\end{array}$ & $\begin{array}{l}\text { Annealing/ } \\
\text { extension } \\
\text { ( } \mathrm{C} / \mathrm{min})\end{array}$ & \\
\hline \multirow{10}{*}{$\begin{array}{l}\text { Viruses } \\
\text { (PCR type 1) }\end{array}$} & \multirow[t]{3}{*}{ Bovine viral diarrhea virus } & BVD-F & GGG NAG TCC & TCA RTG GTT & & & \multirow[t]{3}{*}{ [23] } \\
\hline & & BVD-R & GTG CCA TGT & ACA GCA GAG & VTT TT & & \\
\hline & & BVD-Probe (CY5/BHQ2) & CCA YGT GGA & CGA GGG CAY & & & \\
\hline & \multirow[t]{3}{*}{ Bovine coronavirus } & BCV-F & CTA GTAACC & GG CTG ATG T & СAATA CC & & \multirow[t]{3}{*}{ [12] } \\
\hline & & $B C V-R$ & GGC GGAAAC & CTA GTC GGA & & & \\
\hline & & BCV-Probe (FAM/MGB) & CGC CTG ACA & TTC TCG ATC & & & \\
\hline & \multirow[t]{3}{*}{ Bovine rotavirus } & BRV-F & TCAACATGG & ATG TCC TGTA & T CCT & & \multirow[t]{4}{*}{ [24] } \\
\hline & & BRV-R & TCC CCC AGT & TTG GAA TTC & & & \\
\hline & & BRV-Probe (VIC/MGB) & TCAAAAACT & TT AAA GAT G & AAG & & \\
\hline & Conditions & & $45 / 10$ & $95 / 10$ & $95 / 0.25$ & $60 / 1$ & \\
\hline \multirow{10}{*}{$\begin{array}{l}\text { Bacteria/parasites } \\
\text { (PCR type 2) }\end{array}$} & \multirow[t]{3}{*}{ Escherichia coli K99 } & K99-F & GCT ATT AGT & GT CAT GGC & CT GTA G & & \multirow[t]{3}{*}{ [25] } \\
\hline & & K99-R & TTT GTT TTC & CTAGG CAG & CA TTA & & \\
\hline & & K99-Probe (FAM/BHQ1) & ATT TTAAAC T & AAAAC CAG CC & C CCG GCA & & \\
\hline & \multirow[t]{3}{*}{ Cryptosporidium parvum } & $\begin{array}{l}\text { Cryptosporidium } \\
\text { parvum } \mathrm{F}\end{array}$ & CAAATT GAT & CC GTT TGT C & T TCT GT & & \multirow[t]{3}{*}{ [26] } \\
\hline & & $\begin{array}{l}\text { Cryptosporidium } \\
\text { parvum-R }\end{array}$ & GGC ATG TCG & ATT CTAATT C & G CT & & \\
\hline & & $\begin{array}{l}\text { Cryptosporidium } \\
\text { parvum-Probe } \\
\text { (JOE/BHQ1) }\end{array}$ & TGC CAT ACA & ITG TTG TCC T & GA CAAATT GAA & & \\
\hline & \multirow[t]{3}{*}{ Salmonella species } & Salmonella-F & GGG NAG TCC & TCA RTG GTT & & & \multirow[t]{3}{*}[27]{} \\
\hline & & Salmonella-R & GTG CCA TGT & ACA GCA GAG & VTT TT & & \\
\hline & & $\begin{array}{l}\text { Salmonella-Probe } \\
\text { (CY5/BHQ2) }\end{array}$ & CCA YGT GGA & CGA GGG CAY & & & \\
\hline & \multicolumn{2}{|l|}{ Conditions } & $N / A$ & $95 / 10$ & $95 / 0.25$ & $60 / 1$ & \\
\hline
\end{tabular}

performed using ABI 7500 Fast Real-Time PCR System (Applied Biosystems, Foster City, CA, USA). Cycling conditions of real-time PCR were as follows: (a) reverse transcription (RT) for 30 min at $45^{\circ} \mathrm{C}$; (b) activation of DNA polymerase for 10 min at $95^{\circ} \mathrm{C}$; (c) 40 cycles of denaturation at $94^{\circ} \mathrm{C}$ for $15 \mathrm{sec}$ and annealing/extension at $60^{\circ} \mathrm{C}$ for $60 \mathrm{sec}$. RT step was performed only for viruses. After a 40 cycles reaction, samples with cycle threshold value less than 35 for targets were considered positive. To detect Eimeria spp., all fecal samples were suspended in a solution of 2.5\% potassium dichromate and then transported to the laboratory. In the laboratory, fecal samples were analyzed to detect oocysts using the floatation methods with Sheather's solution (saturated sugar solution; specific gravity 1.28) and examined microscopically ( $\times 400$ magnification) based on the morphological features of the oocysts of the Eimeria spp.

\section{Statistical analysis}

The PCR results for each pathogen were recorded as positive or negative and categorized based on diarrhea status and age group. Age group was divided into three age group $1(1 \mathrm{~d}-10 \mathrm{~d})$, age group 2 (11 d-30 d,), and age group 3 ( $31 \mathrm{~d}-60 \mathrm{~d}$ ). All statistical methods (The $\chi^{2}$, Fischer's exact tests, and linear by linear association) were performed by SPSS v. 25.0 (IBM, Armonk, NY, USA). All graphical works were performed by GraphPad Prism 6 software (GraphPad, San Diego, CA, USA). 


\section{RESULTS}

\section{Relationship between fecal consistency and pathogen presence}

Fecal samples collected from 544 Korean native beef calves on 10 local Korean indigenous cattle farms were described in Table 2. According to our results, diarrhea was not significantly associated with age group. The presence of pathogens in non-diarrheic calves was compared to that in diarrheic calves. Of 340 non-diarrheic calves, 213 calves (62.6\%) were negative and 127 calves (37.4\%) were positive for the pathogens examined. Alternatively, of 204 diarrheic calves, 101 calves (49.5\%) were negative and 103 calves (50.5\%) were positive for the pathogens. The presence of pathogens was significantly associated with diarrhea (odds ratio $=1.71,95 \%$ confidence interval $=1.203-2.431, p<$ 0.01). And also there was a significant linear trend when comparing fecal scores and the number of detected agents (Fig. $1, p<0.001$ ).

The detection of 7 pathogens and relationship between diarrhea and each pathogen The detection rate of the 7 pathogens in the normal feces and diarrheic feces is described in Table 3 . Eimeria spp. (27.4\%) was the most detected pathogen in overall samples, followed by BRV (8.8\%), BCV (8.5\%), C. parvum (4.4\%), BVDV (0.7\%), and E. coli K99 (0.2\%). There was no Salmonella spp. in any our samples. In the diarrheic samples, Eimeria spp. (31.4\%) was detected most often, followed by BRV (15.2\%), BCV (10.3\%), C. parvum (8.3\%), and E. coli K99 (0.5\%). No BVDV or Salmonella spp. was detected. C. parvum $(p=0.001)$ and BRV $(p<0.001)$ had a significantly higher presence in diarrheic calves than in non-diarrheic calves.

\section{Relationship between calves' age and each pathogen}

The detection rate of each pathogen according to age group was also compared (Fig. 2). Eimeria spp. was detected 33.3\% (29/87), 29.5\% (69/234), and 22.9\% (51/223) in age group 1, 2, and 3, respectively. There was a significant linear trend between the detection rate of Eimeria spp. and the age group $(p<0.05)$. BRV was detected 6.9\% (6/87), 10.7\% (25/234), and 7.6\% (17/223) in age group 1,2 , and 3 , respectively. There was no significant linear trend between the detection rate of BRV and the age group. BCV was detected 6.9\% (6/87), 8.5\% (20/234), and 9.0\% (20/223) in age group 1,2, and 3, respectively. There was no significant linear trend between the detection rate of BCV and the age group. C. parvum was detected 6.9\% (6/87), 3.8\% (9/234), and 4.0\% (9/223) in age group 1,2 , and 3, respectively. There was no significant linear trend between the detection rate of C.parvum and the age group. BVDV was detected $0 \%(0 / 87), 0.9 \%(2 / 234)$, and $0.9 \%(2 / 223)$ in age group 1,2 , and 3 , respectively. There was no significant linear trend between the detection rate of BVDV and the age group. E. coli K99 was detected 0\% (0/87), 0\% (0/234), and 0.4\% (1/223) in age group 1,2 , and 3 , respectively. There was no significant linear trend between the detection rate of E. coli K99 and the age group.

\section{DISCUSSION}

In this study, the prevalence of the 7 pathogens in normal and diarrheic calves and the association between the pathogens causing calf diarrhea and the age and fecal status of 544 Korean native beef calves were demonstrated. As expected, diarrheic calves (50.5\%) showed a significantly higher positive rate of pathogens than normal calves (37.4\%), and the fecal consistency had a linear association with the number of detected pathogens, consistent with findings from other countries [13]. This suggested that pathogens were the one of the primary factors related to diarrhea in Korean native beef calves. 
Table 2. Description of calf feces collected

\begin{tabular}{|c|c|c|c|c|c|c|c|c|}
\hline \multirow{3}{*}{ Farm } & \multirow{3}{*}{ Age } & \multicolumn{7}{|c|}{ Fecal score } \\
\hline & & \multicolumn{3}{|c|}{ Normal } & \multicolumn{3}{|c|}{ Diarrhea } & \multirow{2}{*}{ Total } \\
\hline & & 0 & 1 & Subtotal & 2 & 3 & Subtotal & \\
\hline \multirow[t]{4}{*}{ Total } & Age group 1 & 22 & 33 & 55 & 20 & 12 & 32 & 87 \\
\hline & Age group 2 & 59 & 82 & 141 & 57 & 36 & 93 & 234 \\
\hline & Age group 3 & 72 & 72 & 144 & 39 & 40 & 79 & 233 \\
\hline & Subtotal & 153 & 187 & 340 & 116 & 88 & 204 & 544 \\
\hline
\end{tabular}

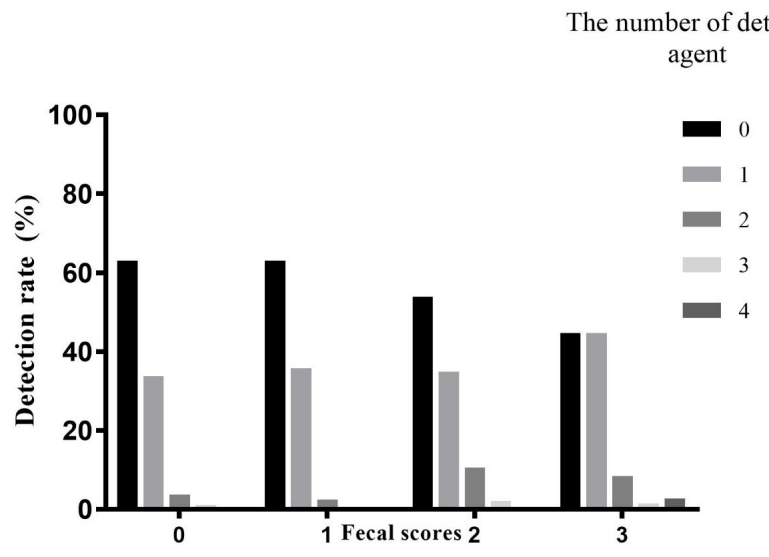

Fig. 1. The comparison of the number of detected pathogens and fecal score in Korean native beef calves. There was a significant linear trend between fecal scores and the number of detected pathogens.

Table 3. Detection frequency of pathogens causing calf diarrhea from non-diarrheic and diarrheic feces of Korean native calves in Korea and association between a positive detection and calf diarrhea

\begin{tabular}{lcccrr}
\hline \multicolumn{1}{c}{ Pathogens } & $\begin{array}{c}\text { Positive in overall } \\
\text { samples }\end{array}$ & $\begin{array}{c}\text { Positive in non- } \\
\text { diarrheic calves }\end{array}$ & $\begin{array}{c}\text { Positive in } \\
\text { diarrheic calves }\end{array}$ & p-value & Odds ratio \\
\hline Eimeria species & $27.4 \%(149 / 544)$ & $25.0 \%(85 / 340)$ & $31.4 \%(64 / 340)$ & 0.113 & $1.37(0.93-2.01)^{1)}$ \\
Bovine rotavirus group A & $8.8 \%(48 / 544)$ & $5.0 \%(17 / 340)$ & $15.2 \%(31 / 204)$ & $<0.001$ & $3.41(1.83-6.33)$ \\
Bovine Coronavirus & $8.5 \%(46 / 544)$ & $7.4 \%(25 / 340)$ & $10.3 \%(21 / 204)$ & 0.266 & $1.45(0.79-2.66)$ \\
Cryptosporidium parvum & $4.4 \%(24 / 544)$ & $2.1 \%(7 / 340)$ & $8.3 \%(17 / 204)$ & 0.001 & $4.33(1.76-10.62)$ \\
BVDV & $0.7 \%(4 / 544)$ & $1.2 \%(4 / 340)$ & $0 \%(0 / 204)$ & 0.302 & $0.99(0.98-1.00)$ \\
Escherichia coli K99 & $0.2 \%(1 / 544)$ & $0 \%(0 / 340)$ & $0.5 \%(1 / 204)$ & 0.375 & $1.005(1.00-1.02)$ \\
Salmonella species & $0 \%(0 / 544)$ & $0 \%(0 / 340)$ & $0 \%(0 / 204)$ & - & - \\
\hline
\end{tabular}

${ }^{1}$ Number in parentheses is the $95 \%$ confidence interval of the estimated odds ratio.

Three viruses (BRV, BCV, and BVDV) were detected in Korean native beef calves. BRV was detected $15.2 \%$ in Korean native beef calves and significantly related to diarrhea $(p<0.001)$. In other reports in Korea, BRV was detected in 34.8\% from diarrhea feces in Korean native calves [14], which might be come from the difference of regions, research periods, and methodology. However, these results including previous reports demonstrate that rotavirus is an important pathogen that can negatively affect the health of calves, consistent with that of earlier reports $[13,15]$. BCV was detected in non-diarrheic and diarrheic calves and there was no significant difference. Even though $\mathrm{BCV}$ is known as one of the main pathogens associated with calf diarrhea, this result that $\mathrm{BCV}$ were detected in normal feces was similar to that seen in earlier reports $[3,16]$. BVDV was detected in only 4 calves and all of them were in the non-diarrheic group. The detection rate of BVDV in this study was less than that in previous research [17]. This result might come from the type of 


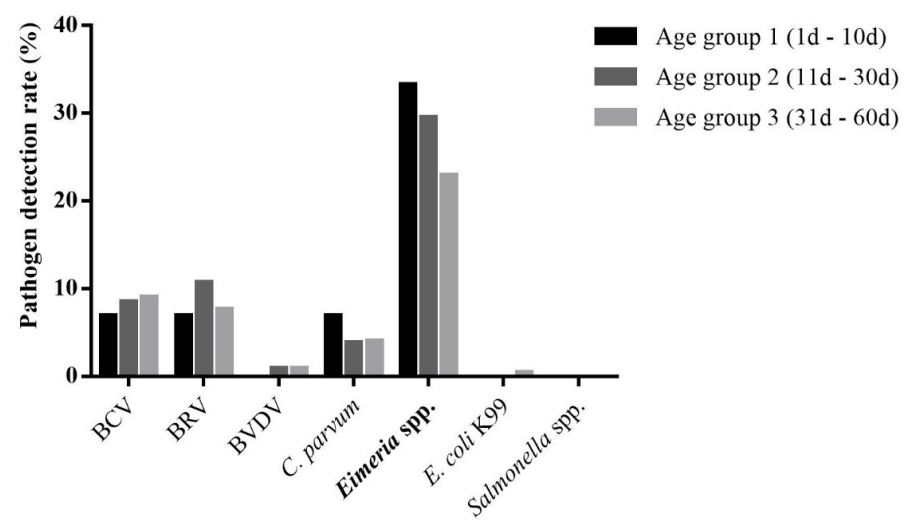

Fig. 2. The pathogen detection rates of 7 pathogens causing calf diarrhea in Korean native beef calves. The bold pathogen has a significant linear trend associated with age group. BCV, bovine coronavirus; BRV, bovine rotavirus group A; BVDV, bovine viral diarrhea virus; C. parvum, Cryptosporidium parvum; E. coli, Escherichia coli.

samples. Feces were used to detect BVDV in this research, however, ear notch, skin fold biopsies, and nasal swabs showed reliable results for the detection of BVDV than rectal swab [18].

Even though the detection rate of C.parvum was lower than that for Eimeria spp. and BCV, C. parvum was found at a significantly higher rate in diarrheic calves than in normal feces, similar to BRV. There have been many reports emphasizing the effects of $C$. parvum infection in calf diarrhea in other countries $[3,13,19]$. Because there is no worldwide commercial vaccine for C. parvum, maintaining good herd sanitation and keeping sick calves away from non-diarrheic calves are important in preventing C. parvum infections.

Two bacteria (E. coli K99 and Salmonella spp.) were selected in this research. There was only one calf positive for $E$. coli $\mathrm{K} 99$ in this research. This result was consistent with that of other reports in Korea that no E. coli strain expressing K99 was detected in isolated samples from cattle farms [20]. Salmonella spp. occurring calf diarrhea was not detected in this research. However, since Salmonella infection in other livestock and human have been reported in Korea [21,22], it is necessary to conduct ongoing monitoring of Salmonella infection in Korean beef calves.

In this study, Eimeria spp. was the most detected pathogen of the 7 examined pathogens and this detection rate was similar to that in other reports from Korea [8]. However, no significant difference was shown between non-diarrheic calves and diarrheic calves. Because Eimeria spp. was also detected frequently in the feces of non-diarrheic calves [23], this result was conceivable. The amount of oocyte secretion was not investigated in this research, but the amount of oocytes excretion of Eimeria spp. is known to be strongly correlated with diarrhea, and thus, further research

Table 4. The detection rate of Eimeria spp. from Korean native calves by age group and fecal status

\begin{tabular}{|c|c|c|c|c|c|}
\hline Fecal status & Age group & Eimeria spp. negative (\%) & Eimeria spp. positive (\%) & Total & $p$-value (linear for trend) \\
\hline \multirow[t]{4}{*}{ Normal } & $1(1-10)$ & $36(65.5)$ & $19(34.5)$ & 55 & 0.008 \\
\hline & $2(11-30)$ & $101(71.6)$ & $40(28.4)$ & 141 & \\
\hline & $3(31-60)$ & $118(81.9)$ & $26(18.1)$ & 144 & \\
\hline & Total & $255(75.0)$ & $85(25.0)$ & 340 & \\
\hline \multirow[t]{4}{*}{ Diarrhea } & $1(1-10)$ & $22(68.8)$ & $10(31.3)$ & 32 & 0.956 \\
\hline & $2(11-30)$ & $64(68.8)$ & $29(31.2)$ & 93 & \\
\hline & $3(31-60)$ & $54(68.4)$ & $25(31.6)$ & 79 & \\
\hline & Total & $140(68.6)$ & $64(31.4)$ & 204 & \\
\hline
\end{tabular}


should investigate the correlation between diarrhea in Korean native beef calves and the amount of Eimeria spp. excreted.

In comparing the age groups among calves to the pathogens detected, only Eimeria spp. showed a linear association to the age groups (Fig. 2). The prevalence of Eimeria infections in normal calves decreased as the age increased $(p<0.01$, linear trend), while in diarrheic calves, the prevalence was stable even as the age increased (Table 4). According to this result, ongoing investigations of the amount of Eimeria spp. infection are important in predicting the pattern of calf diarrhea by Eimeria speices.

In conclusion, six of seven pathogens were detected in samples, but only C.parvum and bovine rotavirus were found at significantly higher rates in diarrheic feces than in non-diarrheic feces and Eimeria spp. showed a significant linear trend between the detection rate of the pathogen and the age groups.

\section{REFERENCES}

1. Cho YI, Yoon KJ. An overview of calf diarrhea - infectious etiology, diagnosis, and intervention. J Vet Sci. 2014;15:1-17.https://doi.org/10.4142/jvs.2014.15.1.1

2. Pereira RV, Adams-Progar AL, Moore DA. Dairy calf treatment for diarrhea: are the drugs we use effective? [Internet] Washington State University Extension. 2017 [cited 2021 Feb 12]. https://hdl.handle.net/2376/11916

3. Izzo MM, Kirkland PD, Mohler VL, Perkins NR, Gunn AA, House JK. Prevalence of major enteric pathogens in Australian dairy calves with diarrhoea. Aust Vet J. 2011;89:167-73. https://doi.org/10.1111/j.1751-0813.2011.00692.x

4. Peter SG, Gitau GK, Richards S, Vanleeuwen JA, Uehlinger F, Mulei CM, et al. Risk factors associated with Cryptosporidia, Eimeria, and diarrhea in smallholder dairy farms in Mukurwe-ini Sub-County, Nyeri County, Kenya. Vet World. 2016;9:811-9. https://doi. org/10.14202/vetworld.2016.811-819

5. Uhde FL, Kaufmann T, Sager H, Albini S, Zanoni R, Schelling E, et al. Prevalence of four enteropathogens in the faeces of young diarrhoeic dairy calves in Switzerland. Vet Rec. 2008;163:362-6. https://doi.org/10.1136/vr.163.12.362

6. Hur TY, Jung YH, Choe CY, Cho YI, Kang SJ, Lee HJ, et al. The dairy calf mortality: the causes of calf death during ten years at a large dairy farm in Korea. Korean J Vet Res. 2013;53:103-8. https://doi.org/10.14405/kjvr.2013.53.2.103

7. Kim UH, Jung YH, Choe C, Kang SJ, Chang SS, Cho SR, et al. Korean native calf mortality: the causes of calf death in a large breeding farm over a 10-year period. Korean J Vet Res. 2015;55:75-80. https://doi.org/10.14405/kjvr.2015.55.2.75

8. Kim HC, Choe C, Kim SH, Chae JS, Yu DH, Park J, et al. Epidemiological survey on Eimeria spp. Associated with diarrhea in Pre-weaned native Korean calves. Korean J Parasitol. 2018;56:619-23. https://doi.org/10.3347/kjp.2018.56.6.619

9. Lee SH, VanBik D, Kim HY, Lee YR, Kim JW, Chae M, et al. Multilocus typing of Cryptosporidium spp. in young calves with diarrhea in Korea. Vet Parasitol. 2016;229:81-9. https:// doi.org/10.1016/j.vetpar.2016.09.019

10. Park J, Han DG, Kim SH, Chae JB, Chae JS, Yu DH, et al. Prevalence of coronavirus from diarrheic calves in the Republic of Korea. Asian Pac J Trop Biomed. 2018;8:1-6. https://doi. org/10.4103/2221-1691.221037

11. University of Wisconsin-Madison School of Veterinary Medicine. Calf health scoring chart [Internet]. 2015 [cited 2016 Feb 20]. https://fyi.extension.wisc.edu/heifermgmt/ files/2015/02/calf_health_scoring_chart.pdf 
12. Cho YI, Kim WI, Liu S, Kinyon JM, Yoon KJ. Development of a panel of multiplex real-time polymerase chain reaction assays for simultaneous detection of major agents causing calf diarrhea in feces. J Vet Diagn Invest. 2010;22:509-17. https://doi. org/10.1177/104063871002200403

13. Cho YI, Han JI, Wang C, Cooper V, Schwartz K, Engelken T, et al. Case-control study of microbiological etiology associated with calf diarrhea. Vet Microbiol. 2013;166:375-85. https:// doi.org/10.1016/j.vetmic.2013.07.001

14. Lee SH, Kim HY, Choi EW, Kim D. Causative agents and epidemiology of diarrhea in Korean native calves.J Vet Sci. 2019;20:e64. https://doi.org/10.4142/jvs.2019.20.e64

15. Bartels CJM, Holzhauer M, Jorritsma R, Swart WAJM, Lam TJGM. Prevalence, prediction and risk factors of enteropathogens in normal and non-normal faeces of young Dutch dairy calves. Prev Vet Med. 2010;93:162-9. https://doi.org/10.1016/j.prevetmed.2009.09.020

16. Kirisawa R, Takeyama A, Koiwa M, Iwai H. Detection of bovine torovirus in fecal specimens of calves with diarrhea in Japan. J Vet Med Sci. 2007;69:471-6. https://doi.org/10.1292/ jvms.69.471

17. Han DG, Ryu JH, Park J, Choi KS. Identification of a new bovine viral diarrhea virus subtype in the Republic of Korea. BMC Vet Res. 2018;14:233. https://doi.org/10.1186/s12917-0181555-4

18. VanderLey B, Ridpath J, Sweiger S. Comparison of detection of bovine virus diarrhea virus antigen in various types of tissue and fluid samples collected from persistently infected cattle. J Vet Diagn Invest. 2011;23:84-6. https://doi.org/10.1177/104063871102300112

19. Trotz-Williams LA, Jarvie BD, Martin SW, Leslie KE, Peregrine AS. Prevalence of Cryptosporidium parvum infection in southwestern Ontario and its association with diarrhea in neonatal dairy calves. Can Vet J. 2005;46:349-51.

20. Shin SW, Byun JW, Jung M, Shin MK, Yoo HS. Antimicrobial resistance, virulence genes and PFGE-profiling of Escherichia coli isolates from South Korean cattle farms. J Microbiol. 2014;52:785-93. https://doi.org/10.1007/s12275-014-4166-1

21. Kang MS, Oh JY, Kwon YK, Lee DY, Jeong OM, Choi BK, et al. Public health significance of major genotypes of Salmonella enterica serovar Enteritidis present in both human and chicken isolates in Korea. Res Vet Sci. 2017;112:125-31. https://doi.org/10.1016/j.rvsc.2017.02.010

22. Oh SI, Kim JW, Chae M, Jung JA, So B, Kim B, et al. Characterization and antimicrobial resistance of Salmonella Typhimurium isolates from clinically diseased pigs in Korea. J Food Prot. 2016;79:1884-90. https://doi.org/10.4315/0362-028X.JFP-16-131

23. Gulliksen SM, Jor E, Lie KI, Hamnes IS, Løken T, Åkerstedt J, et al. Enteropathogens and risk factors for diarrhea in Norwegian dairy calves. J Dairy Sci. 2009;92:5057-66. https://doi. org/10.3168/jds.2009-2080

24. Mahlum CE, Haugerud S, Shivers JL, Rossow KD, Goyal SM, Collins JE, et al. Detection of bovine viral diarrhea virus by $\mathrm{TaqMan}{ }^{\circledR}$ reverse transcription polymerase chain reaction. J Vet Diagn Invest. 2002;14:120-5. https://doi.org/10.1177/104063870201400205

25. West DM, Sprigings KA, Cassar C, Wakeley PR, Sawyer J, Davies RH. Rapid detection of Escherichia coli virulence factor genes using multiplex real-time TaqMan ${ }^{\circledR} \mathrm{PCR}$ assays. Vet Microbiol. 2007;122:323-31. https://doi.org/10.1016/j.vetmic.2007.01.026

26. Guy RA, Payment P, Krull UJ, Horgen PA. Real-time PCR for quantification of Giardia and Cryptosporidium in environmental water samples and sewage. Appl Environ Microbiol. 2003;69:5178-85. https://doi.org/10.1128/AEM.69.9.5178-5185.2003

27. Moore MM, Feist MD. Real-time PCR method for Salmonella spp. targeting the stn gene. J Appl Microbiol. 2006;102:516-30. https://doi.org/10.1111/j.1365-2672.2006.03079.x 